\title{
Synthesis, Crystal Structure and Electrical Properties of the Molybdenum Oxide $\mathrm{Na}_{1.92} \mathrm{Mg}_{2.04} \mathrm{Mo}_{3} \mathrm{O}_{12}$
}

\author{
Ennajeh Ines, Mohamed Faouzi Zid, and Ahmed Driss \\ Laboratoire de Matériaux et Cristallochimie, Faculté des Sciences de Tunis, Université de Tunis El Manar, Manar II, 2092 Tunis, Tunisia \\ Correspondence should be addressed to Mohamed Faouzi Zid; faouzi.zid@fst.rnu.tn
}

Received 28 May 2013; Accepted 4 August 2013

Academic Editors: M. Akkurt, J. Jasinski, J.-P. Lang, and D. Sun

Copyright (C) 2013 Ennajeh Ines et al. This is an open access article distributed under the Creative Commons Attribution License, which permits unrestricted use, distribution, and reproduction in any medium, provided the original work is properly cited.

New molybdenum oxide $\mathrm{Na}_{1.92} \mathrm{Mg}_{2.04} \mathrm{Mo}_{3} \mathrm{O}_{12}$ has been synthesized by the solid state method. The title compound crystallizes in the triclinic system (space group P-1). The unit cell parameters are $a=6.9660(7) \AA, b=8.6352(8) \AA, c=10.2501(8) \AA, \alpha=106.938(1)^{\circ}$, $\beta=104.825(1)^{\circ}, \gamma=103.206(1)^{\circ}, V=538.72(9) \AA^{3}$, and $Z=2$. The compound is isotypical to $\mathrm{Ag}_{2} \mathrm{M}_{2}\left(\mathrm{MoO}_{4}\right)_{3}(\mathrm{M}=\mathrm{Zn}, \mathrm{Mg}, \mathrm{Co}, \mathrm{Mn})$. The structure can be described as a three-dimensional anionic mixed framework of $\mathrm{MoO}_{4}$ tetrahedra and pairs of $\mathrm{Mg}_{2} \mathrm{O}_{10}$ octahedra sharing common edges. The $\mathrm{Na}^{+}$ions are disordered and located in the voids forming infinite channels running along the direction [100]. The electrical conductivity investigated from $693 \mathrm{~K}$ to $793 \mathrm{~K}$ by AC impedance spectroscopy is low $\left(3.01 \times 10^{-7} \mathrm{~S} \mathrm{~cm}^{-1}\right.$ at $683 \mathrm{~K})$.

\section{Introduction}

The interest in the study of alkali molybdenum oxides is primarily in the unique structural and physical properties of some of these compounds which include high anisotropic transport properties $[1,2]$ and superconductivity and in their important application in the field of energy and electronics as described in several reviews $[3,4]$. Some of complex molybdates crystallize in structure types which show significant ionic conductivity. For example, the structure of the Nasicon type molybdate [5] is of great interest because of high ionic conduction. For this reason the characterization of those oxides seems to be an important task. In our investigation, we synthesize new crystal of molybdenum oxide $\mathrm{Na}_{1.92} \mathrm{Mg}_{2.04} \mathrm{Mo}_{3} \mathrm{O}_{12}$.

In our bibliographical search, we found the study of the phase diagram of the system $\mathrm{Na}_{2} \mathrm{MoO}_{4}-\mathrm{MgMoO}_{4}$ [6]; the system contains a single intermediate compound $\mathrm{Na}_{2} \mathrm{Mg}_{5}$ $\left(\mathrm{MoO}_{4}\right)_{6}$ [7]. The structural study reveals that the compound is isotypical to $\mathrm{Na}_{2} \mathrm{Mg}_{5}\left(\mathrm{MoO}_{4}\right)_{6}$ [7], $\mathrm{Ag}_{2} \mathrm{M}_{2}\left(\mathrm{MoO}_{4}\right)_{3}(\mathrm{M}=$ $\mathrm{Co}, \mathrm{Mn}, \mathrm{Mg}, \mathrm{Zn})$ [8-10], and $\mathrm{Na}_{0.5} \mathrm{Zn}_{2.75}\left(\mathrm{MoO}_{4}\right)_{3}$ [11].

(The cif file corresponding to the studied structure has been deposited in the database of Karlsruhe Number CSD. 426651 (http://www.fiz-karlsruhe.de/icsd.html)).

\section{Experimental Details}

2.1. Synthesis. The compound is synthesized by the solid state method. A stoichiometric mixture of $\mathrm{NaCO}_{3}$ (Fluka, 71350), $\left(\mathrm{NH}_{4}\right)_{2} \mathrm{Mo}_{4} \mathrm{O}_{13}$ (Fluka, 69858), and $\mathrm{Mg}\left(\mathrm{NO}_{3}\right)_{2} \cdot 6 \mathrm{H}_{2} \mathrm{O}$ (Fluka, 63079), placed in a porcelain crucible, is slowly annealed in air at $350^{\circ} \mathrm{C}$ for 12 hours, in order to eliminate volatile products. The resulting mixtures were heated at $540^{\circ} \mathrm{C}$ for 7 days in air. Then, they were slowly cooled at $5^{\circ} \mathrm{C} /$ day to $490^{\circ} \mathrm{C}$ and finally, they were cooled at $50^{\circ} \mathrm{C} /$ day to room temperature. Single colorless crystals of double molybdates were grown by spontaneous crystallizations from stoichiometric melts. The compound is isotypical to $\mathrm{Na}_{2} \mathrm{Mg}_{5}\left(\mathrm{MoO}_{4}\right)_{6}$ [4] and $\mathrm{Ag}_{2} \mathrm{M}_{2}\left(\mathrm{MoO}_{4}\right)_{3}(\mathrm{M}=\mathrm{Co}, \mathrm{Mn}, \mathrm{Mg}, \mathrm{Zn})$ [7-9] and contains mixed frameworks of $\mathrm{MoO}_{4}$ tetrahedra and pairs of $\mathrm{MgO}_{6}$ octahedra sharing common edges.

2.2. X-Ray Data Collection. Data collection was performed with a CAD-4 Enraf-Nonius X-ray diffractometer [12] at $298 \mathrm{~K}$ with graphite monochromator using $\mathrm{MoK}_{\alpha}$ wavelength. An empirical psi-scan [13] absorption correction was applied. The structure was solved and refined by fullmatrix least squares based on $F^{2}$ using SHELXS-97 and SHELXL-97 [14, 15], respectively. In the closest solution 


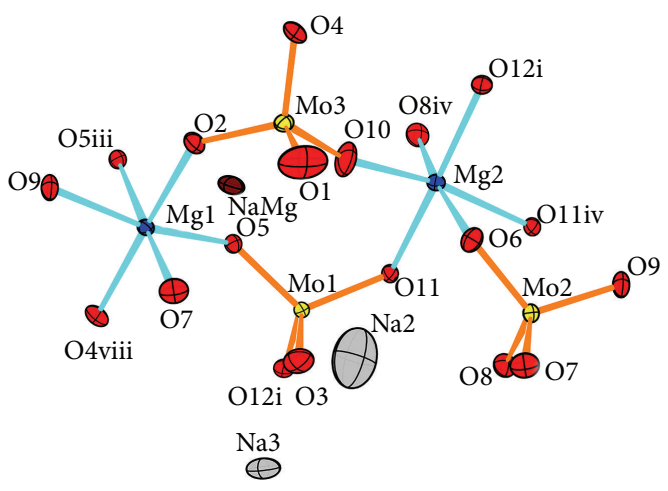

Figure 1: The asymmetric unit of $\mathrm{Na}_{1.92} \mathrm{Mg}_{2.04} \mathrm{Mo}_{3} \mathrm{O}_{12}$ compound.

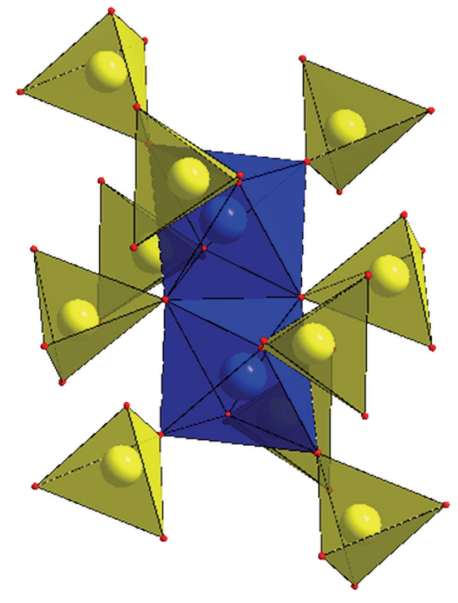

(a)

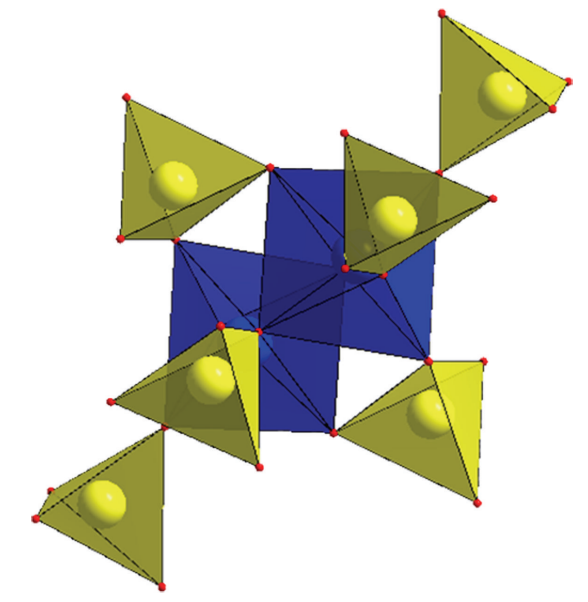

(b)

Figure 2: A view showing (a) $\mathrm{Mg}_{2} \mathrm{Mo}_{10} \mathrm{O}_{40}$ and (b) $\mathrm{Mg}_{2} \mathrm{Mo}_{8} \mathrm{O}_{32}$.

proposed by the program, only some molybdenum atoms and magnesium atoms were located. Using SHELXL-97 program, refinements followed by Fourier differences were necessary to find the positions of the other atoms remaining in the lattice yielding a good $R$ factor of $2.18 \%$ for all reflections and allowing the revolution of the positions of 12 peaks of oxygen atoms on the difference Fourier map. The structure graphics were drawn with diamond 2.1 supplied by Crystal Impact [16]. Crystal data and structure refinements details are summarized in Table 1. The atomic coordinates and isotropic thermal factors are presented in Table 2 . Table 3 contains the main interatomic distances in the coordination polyhedra of the studied structure.

\section{Results and Discussion}

3.1. Structure Description. The title compound is a new member of isostructural phases family including $\mathrm{Na}_{2} \mathrm{Mg}_{5}\left(\mathrm{MoO}_{4}\right)_{6}$ [7], $\mathrm{Ag}_{2} \mathrm{M}_{2}\left(\mathrm{MoO}_{4}\right)_{3}(\mathrm{M}=\mathrm{Co}, \mathrm{Mn}, \mathrm{Mg}, \mathrm{Zn})$ [8-10], and to $\mathrm{Na}_{0.5} \mathrm{Zn}_{2.75}\left(\mathrm{MoO}_{4}\right)_{3}$ [11]. The cell parameters of those compounds are given in Table 4.

The asymmetric unit in $\mathrm{Na}_{1.92} \mathrm{Mg}_{2.04} \mathrm{Mo}_{3} \mathrm{O}_{12}$ compound is shown in Figure 1. The structure is composed of two octahedra $\mathrm{Mg}_{2} \mathrm{O}_{10}$ and three tetrahedra $\mathrm{MoO}_{4}$ sharing corners and forming a cyclic group $\mathrm{Mg}_{2} \mathrm{Mo}_{3} \mathrm{O}_{19}$. The charge compensation in the asymmetric unit is ensured by $\mathrm{Na}^{+}$ cations.

The structure may be represented as a three-dimensional mixed framework of pairs of $\mathrm{MgO}_{6}$ octahedra sharing common edges forming $\mathrm{Mg}_{2} \mathrm{O}_{10}$ group, linked to $\mathrm{MoO}_{4}$ tetrahedra by corners. Each two $\mathrm{Mg}_{2} \mathrm{O}_{10}$ octahedra sharing edges are surrounded either by ten tetrahedra forming $\mathrm{Mg}(1)_{2} \mathrm{Mo}_{10} \mathrm{O}_{40}$ group (Figure 2(a)) or by eight tetrahedra forming $\mathrm{Mg}(2)_{2} \mathrm{Mo}_{8} \mathrm{O}_{32}$ group (Figure 2(b)).

The projection of the structure along [100] and [001] directions shows the presence of layers in the ac plane which are connected by $\mathrm{Mo}(2) \mathrm{O}_{4}$ polyhedra forming two types of tunnels hexagonal along [100] direction (Figure 3) and squared along [001] direction (Figure 4). The monovalent cations are located in tunnels forming infinite channels.

The projection of a layer along the direction [010] shows the presence of two types of $\mathrm{Mg}(1)_{2} \mathrm{Mo}_{10} \mathrm{O}_{40}$ and $\mathrm{Mg}(2)_{2}$ $\mathrm{Mo}_{8} \mathrm{O}_{32}$ chains connected by $\mathrm{MoO}_{4}$ tetrahedra (Figure 5).

In the crystal structure of $\mathrm{Na}_{1.92} \mathrm{Mg}_{2.04} \mathrm{Mo}_{3} \mathrm{O}_{12}$, the Mo atom has a tetrahedral oxygen coordination, with Mo-O distances varying within $1.718(3)-1.800(4) \AA$ with the average 


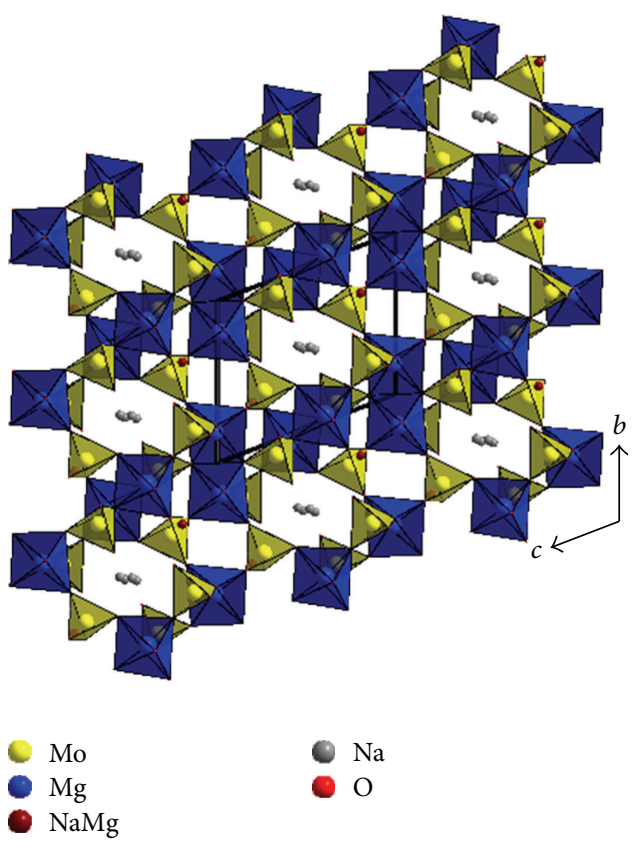

Figure 3: Projection of $\mathrm{Na}_{1.92} \mathrm{Mg}_{2.04} \mathrm{Mo}_{3} \mathrm{O}_{12}$ structure along [100] direction showing cavities where monovalent cations are located.

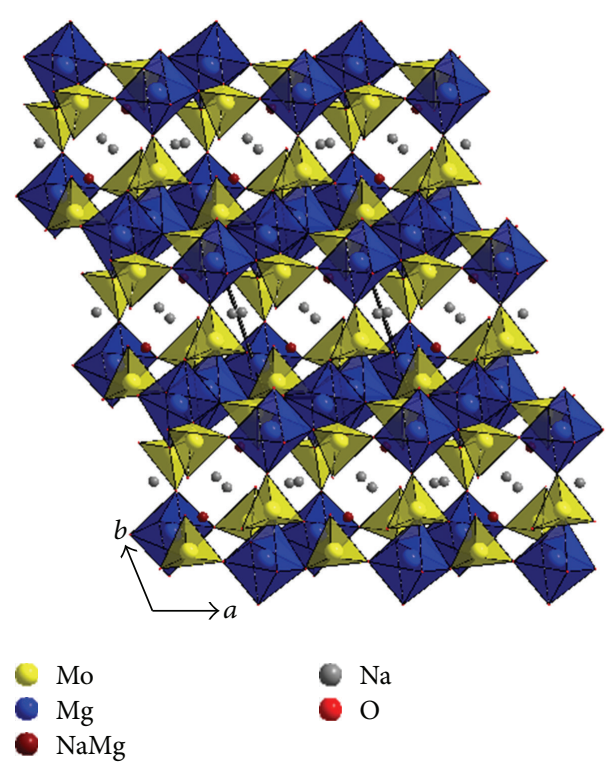

Figure 4: Projection of $\mathrm{Na}_{1.92} \mathrm{Mg}_{2.04} \mathrm{Mo}_{3} \mathrm{O}_{12}$ structure along [001] direction showing layers along a direction.

of $1.760 \AA$ close to the common values [14]. Magnesium cations occupy two crystallographically independent sites Mg1 and Mg2, which are located in an octahedral environment with $(d(\mathrm{Mgl}-\mathrm{O})=2.056(3)-2.167(3) \AA)$ and $(d(\mathrm{Mg} 2-$ $\mathrm{O}=1.989(4)-2.158(3) \AA$ ) with the average of $2.100 \AA$.

Sodium atoms occupy three different positions $\mathrm{Na}(1)$, $\mathrm{Na}(2)$, and the third site which is occupied by $\left(\mathrm{Na}^{+}, \mathrm{Mg}^{2+}\right)$. The (Na1/Mg11)-O bond lengths vary from 2.15 to $2.29 \AA$ (Table 3). In fact, we remark that the short distance $\mathrm{Na}-\mathrm{O}$ is
TABLE 1: Crystal data and structure refinement details for $\mathrm{Na}_{1.92}$ $\mathrm{Mg}_{2.04} \mathrm{Mo}_{3} \mathrm{O}_{12}$.

\begin{tabular}{lc}
\hline Empirical formula & $\mathrm{Na}_{1.92} \mathrm{Mg}_{2.04} \mathrm{Mo}_{3} \mathrm{O}_{12}$ \\
Formula weight $(\mathrm{g} / \mathrm{mol})$ & 573.55 \\
Crystal system, space group & Triclinic, $\mathrm{P}-1$ \\
$a(\AA)$ & $6.9660(7)$ \\
$b(\AA)$ & $8.6352(8)$ \\
$c(\AA)$ & $10.2501(8)$ \\
$\alpha\left(^{\circ}\right)$ & $106.938(1)$ \\
$\beta\left(^{\circ}\right)$ & $104.825(1)$ \\
$\gamma\left(^{\circ}\right)$ & $103.206(1)$ \\
$V\left(\AA^{3}\right)$ & $538.72(9)$ \\
$Z$ & 2 \\
$\mu\left(\mathrm{mm}{ }^{-1}\right)$ & 3.69 \\
$D_{x}\left(\mathrm{~g} \cdot \mathrm{cm}^{-3}\right)$ & 3.536 \\
$F(000)$ & 535 \\
Crystal size $(\mathrm{mm})$ & $0.28 \times 0.18 \times 0.14$ \\
Crystal habit & Colourless prism \\
$T_{\text {min }} / T_{\text {max }}$ & $0.4244 / 0.6258$ \\
Measured reflections & 3666 \\
Independent reflections & 2338 \\
Observed refl. with $I>2 \sigma(I)$ & 2211 \\
$R_{\text {int }}$ & 0.021 \\
Data/restraints/parameters & $2338 / 1 / 184$ \\
$R\left[F^{2}>2 \sigma\left(F^{2}\right)\right]$ & 0.022 \\
$w R\left(F^{2}\right)$ & 0.058 \\
GooF $=S$ & 1.16 \\
$\Delta \rho_{\text {max }} / \Delta \rho_{\text {min }}\left(\mathrm{e} \cdot \AA^{-3}\right)$ & $0.78 /-0.84$ \\
\hline & \\
&
\end{tabular}

shorter than normal which indicates that the occupation is partial with the $\mathrm{M}^{2+}$ atom.

The $(\mathrm{Nal} / \mathrm{Mgll}) \mathrm{O}_{5}$ is surrounded by five oxygen atoms $(\mathrm{CN}=5)$. The voids between layers are occupied by sodium atoms: $\mathrm{Na} 2$ and $\mathrm{Na} 3$ are in the middle of concavities; (Na1/Mg11) lie on the extremity of the concavity attracted to polyhedra of two adjacent layers (Figure 4).

3.2. Electrical Measurements. The electrical properties of $\mathrm{Na}_{1.92} \mathrm{Mg}_{2.04} \mathrm{Mo}_{3} \mathrm{O}_{12}$ ceramic have been investigated using complex impedance spectroscopy. Impedance spectroscopy measurements were carried out in a Hewlett-Packard 4192-A automatic bridge monitored by an HP microcomputer. The electrical measurements are realized in the thermal range $693-743 \mathrm{~K}$ and frequency range of $5 \mathrm{~Hz}-13 \mathrm{MHz}$. Pellet was prepared by isostatic pressing at $4 \mathrm{kbar}$ and sintering at $480^{\circ} \mathrm{C}$ for $2 \mathrm{~h}$ in air with $5 \mathrm{~K} \cdot \mathrm{min}^{-1}$ heating and cooling rates. The thickness and surface of pellet were about $0.159 \mathrm{~cm}$ and $0.807 \mathrm{~cm}^{2}$ having a geometric factor of $e / S=0.197 \mathrm{~cm}^{-1}$. Platinum electrodes were painted in the two faces of the pellet with a platinum paste to ensure good electric contacts. The Nyquist plots at different temperatures are shown in Figure 6. When temperature increases, the radius of semicircles decreases, which indicates an activated conduction 
TABLE 2: Atomic coordinates and isotropic thermal factors of $\mathrm{Na}_{1.92}$ $\mathrm{Mg}_{2.04} \mathrm{Mo}_{3} \mathrm{O}_{12}$.

\begin{tabular}{lccccc}
\hline Atom & $x$ & $y$ & $z$ & $U_{\text {iso }}$ & Occ. $(<1)$ \\
\hline Mo1 & $0.1142(4)$ & $0.0912(4)$ & $0.3329(3)$ & $0.0104(7)$ & \\
Mo2 & $0.7850(4)$ & $0.3354(4)$ & $0.7400(3)$ & $0.0105(7)$ & \\
Mo3 & $0.5948(8)$ & $0.2594(4)$ & $0.1303(4)$ & $0.0133(5)$ & \\
Mg1 & $0.0424(2)$ & $0.2000(8)$ & $0.0174(8)$ & $0.0107(3)$ & \\
Mg2 & $0.6224(2)$ & $0.0434(8)$ & $0.3953(7)$ & $0.0120(3)$ & \\
Na1 & $0.7123(3)$ & $0.7072(2)$ & $0.1966(2)$ & $0.0219(6)$ & $0.917(9)$ \\
Mg11 & $0.7123(3)$ & $0.7072(2)$ & $0.1966(2)$ & $0.0219(6)$ & $0.042(8)$ \\
Na2 & $0.4759(9)$ & $0.5336(9)$ & $0.5487(8)$ & $0.0900(3)$ & 0.50 \\
Na3 & $0.0340(2)$ & $0.507(2)$ & $0.5199(9)$ & $0.0290(2)$ & 0.50 \\
O1 & $0.7258(7)$ & $0.4739(5)$ & $0.2418(5)$ & $0.0544(9)$ & \\
O2 & $0.3473(5)$ & $0.2349(4)$ & $0.0075(3)$ & $0.0198(6)$ & \\
O3 & $0.1729(6)$ & $0.3074(4)$ & $0.4221(4)$ & $0.0283(7)$ & \\
O4 & $0.7536(5)$ & $0.1913(4)$ & $0.0362(3)$ & $0.0221(7)$ & \\
O5 & $0.0790(4)$ & $0.0561(3)$ & $0.1472(3)$ & $0.0124(5)$ & \\
O6 & $0.7797(5)$ & $0.2956(4)$ & $0.5600(3)$ & $0.0177(6)$ & \\
O7 & $0.8334(5)$ & $0.5524(4)$ & $0.8268(3)$ & $0.0229(7)$ & \\
O8 & $0.5351(5)$ & $0.2240(4)$ & $0.7349(3)$ & $0.0184(6)$ & \\
O9 & $0.9802(4)$ & $0.2684(4)$ & $0.8377(3)$ & $0.0178(6)$ & \\
O10 & $0.5657(6)$ & $0.1487(6)$ & $0.2471(4)$ & $0.0363(9)$ & \\
O11 & $0.3273(4)$ & $0.0301(4)$ & $0.4206(3)$ & $0.0132(5)$ & \\
O12 & $0.8781(5)$ & $0.9886(4)$ & $0.3507(3)$ & $0.0184(6)$ & \\
\hline & & & & & \\
& & & & \\
Ond &
\end{tabular}

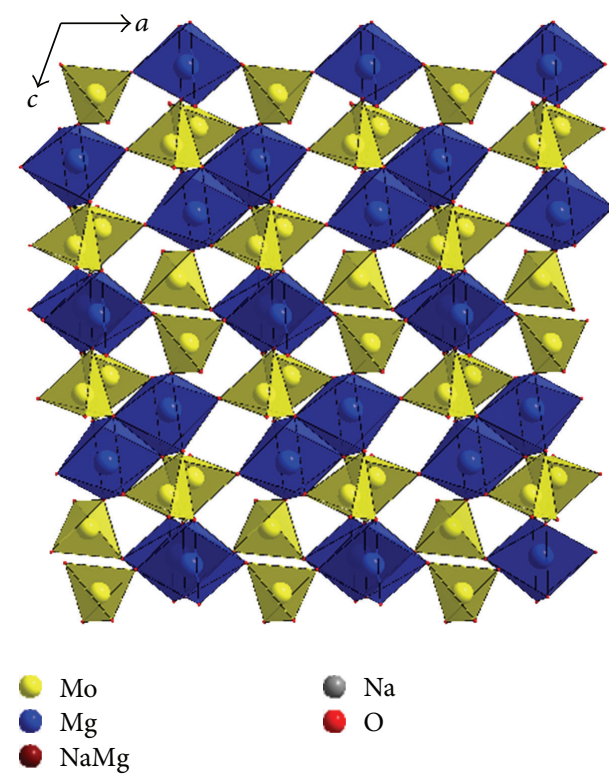

Figure 5: Projection of chains structure along [001] direction showing layers along a direction.

mechanism. The intercepts of the semicircular arcs with the real axis give an estimation of the resistance of material. We have used the Zview software [17] to fit these curves. The measured impedance can be modeled as an equivalent electrical circuit composed of a resistor, $R$, connected in parallel with a constant phase element, CPE [18]. By knowing
TABLE 3: Main interatomic distances $(\AA)$ in $\mathrm{Na}_{1.92} \mathrm{Mg}_{2.04} \mathrm{Mo}_{3} \mathrm{O}_{12}$ compound.

\begin{tabular}{|c|c|}
\hline \multicolumn{2}{|c|}{ Bond distances $(\AA)$} \\
\hline Mo1-O3 & $1.718(3)$ \\
\hline Mo1-O12 & $1.762(3)$ \\
\hline Mo1-O5 & $1.780(3)$ \\
\hline Mo1-O11 & $1.800(3)$ \\
\hline Mo2-O7 & $1.732(3)$ \\
\hline Mo2-O6 & $1.765(3)$ \\
\hline Mo2-O8 & $1.766(3)$ \\
\hline Mo2-O9 & $1.785(3)$ \\
\hline Mo3-O4 & $1.736(3)$ \\
\hline Mo3-O1 & $1.740(4)$ \\
\hline Mo3-O10 & $1.758(3)$ \\
\hline Mo3-O2 & $1.780(3)$ \\
\hline $\mathrm{Mgl}_{-\mathrm{O}}{ }^{\mathrm{vii}}$ & $2.056(3)$ \\
\hline Mg1-O9 $9^{\text {viii }}$ & $2.067(3)$ \\
\hline Mg1-O5 & $2.076(3)$ \\
\hline $\mathrm{Mg1-O7^{ \textrm {ii } }}$ & $2.080(3)$ \\
\hline Mg1-O2 & $2.109(3)$ \\
\hline $\mathrm{Mg1-O} 5^{\mathrm{iii}}$ & $2.167(3)$ \\
\hline Mg2-O10 & $1.989(4)$ \\
\hline $\mathrm{Mg} 2-\mathrm{O} 12^{\mathrm{ix}}$ & $2.070(3)$ \\
\hline Mg2-O11 & $2.119(3)$ \\
\hline $\mathrm{Mg} 2-\mathrm{O} 11^{\text {iv }}$ & $2.132(3)$ \\
\hline Mg2-O6 & $2.148(3)$ \\
\hline $\mathrm{Mg} 2-\mathrm{O} 8^{\text {iv }}$ & $2.149(3)$ \\
\hline $\mathrm{Na1}-\mathrm{O} 8^{\mathrm{ii}}$ & $2.158(3)$ \\
\hline Nal-O1 & $2.211(6)$ \\
\hline $\mathrm{Na} 1-\mathrm{O}^{\mathrm{v}}$ & $2.232(3)$ \\
\hline $\mathrm{Nal}-\mathrm{O} 2^{\mathrm{vi}}$ & $2.250(3)$ \\
\hline Na1-O12 & $2.298(4)$ \\
\hline $\mathrm{Na} 2-\mathrm{O} 3$ & $2.279(8)$ \\
\hline $\mathrm{Na} 2-\mathrm{O} 3^{\mathrm{ii}}$ & $2.411(9)$ \\
\hline $\mathrm{Na} 2-\mathrm{O} 6^{\mathrm{ii}}$ & $2.780(3)$ \\
\hline $\mathrm{Na} 2-\mathrm{O} 1^{\mathrm{ii}}$ & $2.859(9)$ \\
\hline $\mathrm{Na} 3-\mathrm{O} 3$ & $2.272(18)$ \\
\hline $\mathrm{Na} 3-\mathrm{O}^{\mathrm{ii}}$ & $2.371(19)$ \\
\hline $\mathrm{Na} 3-\mathrm{O} 3^{\mathrm{x}}$ & $2.437(17)$ \\
\hline $\mathrm{Na} 3-\mathrm{O}^{\mathrm{vii}}$ & $2.440(19)$ \\
\hline $\mathrm{Na} 3-\mathrm{O} 1^{\mathrm{ii}}$ & $2.518(11)$ \\
\hline $\mathrm{Na} 3-\mathrm{O}^{\mathrm{vii}}$ & $2.989(10)$ \\
\hline
\end{tabular}

the value of resistance and the dimensions of the sample, the conductivity has been calculated at each temperature.

The variation of $\log \left(\sigma T\left(\mathrm{~S} \cdot \mathrm{K} \cdot \mathrm{cm}^{-1}\right)\right)$ versus $1000 / T\left(\mathrm{~K}^{-1}\right)$ is represented in Figure 7. The conductivity value at $683 \mathrm{~K}$ is $3.01 \times 10^{-7} \mathrm{~S} \mathrm{~cm}^{-1}$ and the activation energy for $\mathrm{Na}^{+}$ ions migration deduced from the slope is $\mathrm{Ea}=1.37 \mathrm{eV}$; $\mathrm{Na}_{1.92} \mathrm{Mg}_{2.04} \mathrm{Mo}_{3} \mathrm{O}_{12}$ shows a low electric conductivity, when 


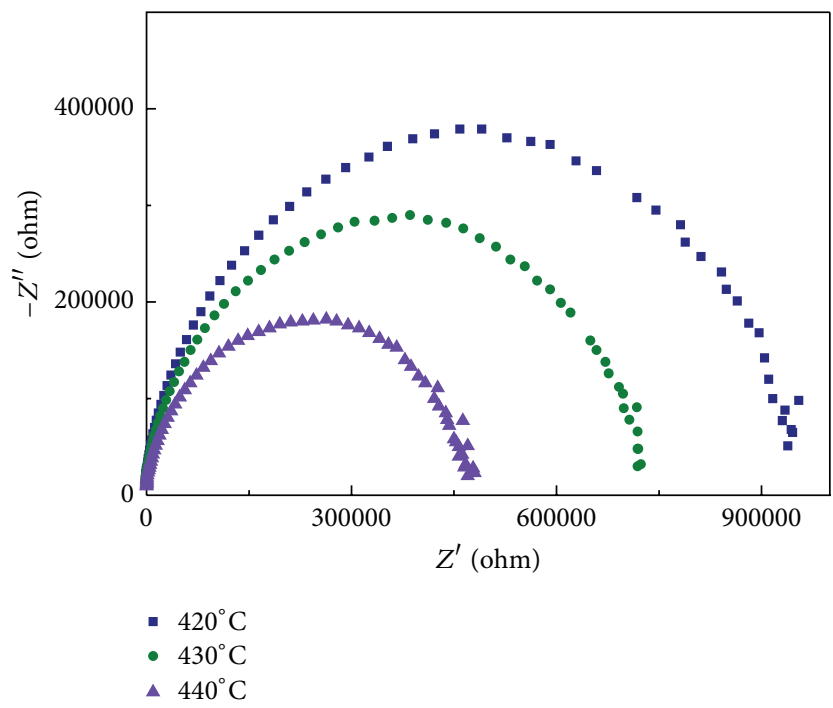

(a)

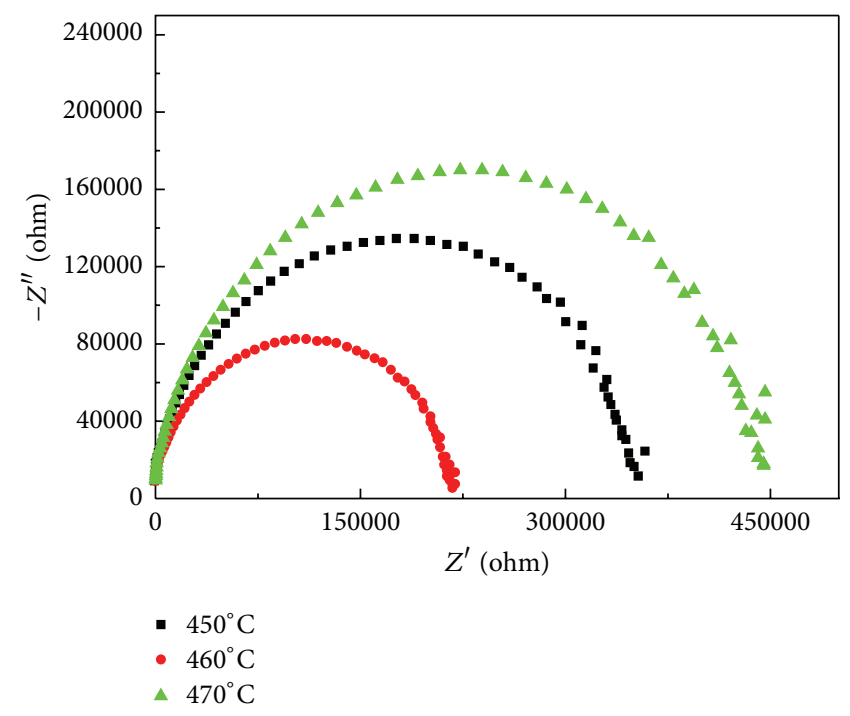

(b)

FIgURE 6: Complex impedance spectra of $\mathrm{Na}_{1.92} \mathrm{Mg}_{2.04} \mathrm{Mo}_{3} \mathrm{O}_{12}$ at various temperatures.

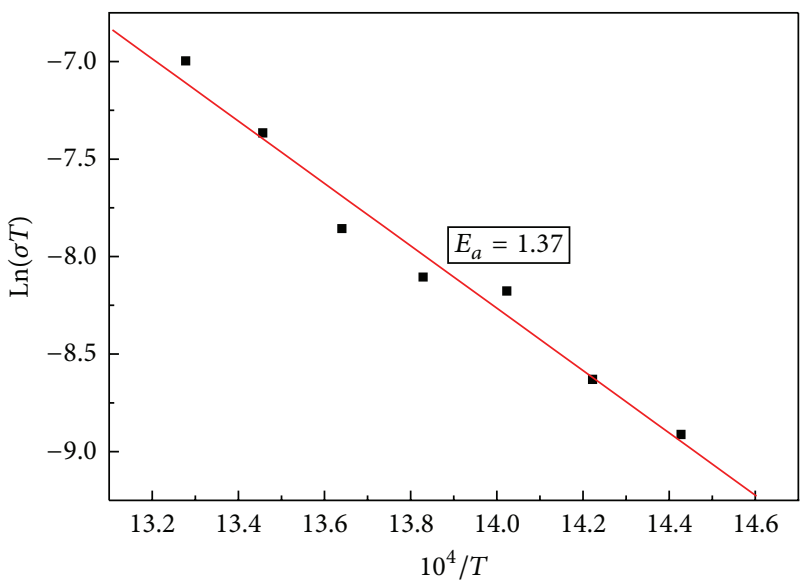

Figure 7: Arrhenius plot of conductivity of $\mathrm{Na}_{1.92} \mathrm{Mg}_{2.04} \mathrm{Mo}_{3} \mathrm{O}_{12}$ ceramic.

compared to those found for other molybdenum oxide compounds (Table 5) $[19,20]$.

\section{Conclusion}

New molybdate $\mathrm{Na}_{1.92} \mathrm{Mg}_{2.04} \mathrm{Mo}_{3} \mathrm{O}_{12}$ is synthesized by a solid state method. The structure of our compound has been solved by using X-ray diffraction. The compound is formed by bioctahedra $\mathrm{M}_{2} \mathrm{O}_{10}$ and $\mathrm{MoO}_{4}$ tetrahedra connected via common vertices. The structure of this material has an open framework having different interconnecting tunnels running along [100] and [001] where the $\mathrm{Na}^{+}$ions are located. The electrical properties of the title compound are investigated using complex impedance spectroscopy. The conductivity value at $683 \mathrm{~K}$ is $3.01 \times 10^{-7} \mathrm{~S} \mathrm{~cm}^{-1}$ and the activation energy
TABLE 4: Cell parameters of isotypical compounds.

\begin{tabular}{lll}
\hline Compound & Space group & Cell parameters $\left(\AA,^{\circ}\right)$ \\
\hline & & $10.575(5) 8.617(4) 6.951(3)$ \\
$\mathrm{Na}_{2} \mathrm{Mg}_{5}\left(\mathrm{MoO}_{4}\right)_{6}$ & Triclinic P-1 & $103.42(4) 102.67(4)$ \\
& & $112.37(3)$ \\
& & $V=535.38 \AA^{3}$ \\
& & $6.978(1) 8.715(2) 10.294(2)$ \\
$\mathrm{Ag}_{2} \mathrm{Mg}_{2}\left(\mathrm{MoO}_{4}\right)$ & Triclinic P-1 & $107.56(1) 105.11(1) 103.68(1)$ \\
& & $V=541.38 \AA^{3}$ \\
& & $6.989(1) 8.738(2) 10.295(2)$ \\
$\mathrm{Ag}_{2} \mathrm{Co}_{2}\left(\mathrm{MoO}_{4}\right)$ & Triclinic P-1 & $107.67(2) 105.28(2) 103.87(2)$ \\
& & $V=541.79 \AA^{3}$ \\
& & $6.992(6) 8.712(7) 10.818(7)$ \\
$\mathrm{Ag}_{2} \mathrm{Zn}_{2}\left(\mathrm{MoO}_{4}\right)$ & Triclinic P-1 & $64.24(2) 66.51(2) 76.27(3)$ \\
& & $V=542.66 \AA^{3}$ \\
& & 6.9838 .59410 .82565 .877 \\
$\mathrm{Na}_{0.5} \mathrm{Zn}_{2.75}\left(\mathrm{MoO}_{4}\right)_{3}$ & Triclinic P-1 & 66.1978 .17 \\
& & $V=541.81 \AA^{3}$ \\
\hline
\end{tabular}

TABLE 5: Conductivity $\sigma\left(\mathrm{S} \cdot \mathrm{cm}^{-1}\right)$ and conduction activation energy $E_{a}(\mathrm{eV})$ of other compounds.

\begin{tabular}{lccc}
\hline Compound & $\begin{array}{c}\text { Temperature } \\
\text { range }\left({ }^{\circ} \mathrm{C}\right)\end{array}$ & $E_{a}(\mathrm{eV})$ & $\sigma\left(\mathrm{S} \cdot \mathrm{cm}^{-1}\right)$ \\
\hline $\mathrm{Li}_{3} \mathrm{Cr}\left(\mathrm{MoO}_{4}\right)_{3}$ & $200-400$ & 1.06 & $2.6 \times 10^{-6}\left(300^{\circ} \mathrm{C}\right)$ \\
$\mathrm{Na}_{5} \mathrm{Sc}\left(\mathrm{MoO}_{4}\right)_{3}$ & - & 0.72 & $6 \times 10^{-6}\left(300^{\circ} \mathrm{C}\right)$ \\
$\mathrm{Li}_{2} \mathrm{Mg}_{2}\left(\mathrm{MoO}_{4}\right)_{3}$ & $200-400$ & 0.71 & $1.1 \times 10^{-7}\left(300^{\circ} \mathrm{C}\right)$ \\
$\mathrm{Na}_{2} \mathrm{In}_{2} \mathrm{Mo}_{5} \mathrm{O}_{16}$ & - & 0.79 & $2 \times 10^{-7}\left(275^{\circ} \mathrm{C}\right)$ \\
$\mathrm{Li}_{1.8} \mathrm{Mg}_{2.1}\left(\mathrm{MoO}_{4}\right)_{3}$ & $200-400$ & 0.63 & $6.1 \times 10^{-8}\left(300^{\circ} \mathrm{C}\right)$ \\
$\mathrm{Li}_{1.6} \mathrm{Mg}_{2.2}\left(\mathrm{MoO}_{4}\right)_{3}$ & $200-400$ & 0.76 & $1.4 \times 10^{-8}\left(300^{\circ} \mathrm{C}\right)$ \\
\hline
\end{tabular}

for $\mathrm{Na}^{+}$ions migration is $\mathrm{Ea}=1.37 \mathrm{eV} . \mathrm{Na}_{1.92} \mathrm{Mg}_{2.04} \mathrm{Mo}_{3} \mathrm{O}_{12}$ presents a low electric conductivity. 


\section{References}

[1] T. Minami, K. Imazawa, and M. Tanaka, "Formation region and characterization of superionic conducting glasses in the systems AgI-Ag $\mathrm{O}_{2}-\mathrm{M}_{x} \mathrm{O}_{y}$," Journal of Non-Crystalline Solids, vol. 42, no. 1-3, pp. 469-476, 1980.

[2] A. L. Laskar and S. Chandra, Eds., Superionic Solids and Solid Electrolytes-Recent Trends, Academic Press, San Diego, Calif, USA, 1989.

[3] I. Y. Kotova and N. M. Kozhevnikova, "Phase relations in the $\mathrm{Na}_{2} \mathrm{MoO}_{4}-\mathrm{MgMoO}_{4}-\mathrm{Cr}_{2}\left(\mathrm{MoO}_{4}\right)_{3}$ system," Inorganic Materials, vol. 34, no. 10, pp. 1068-1070, 1998.

[4] I. Y. Kotova and N. M. Kozhevnikova, "Phase relations and electrical properties of phases in systems $\mathrm{Na}_{2} \mathrm{MoO}_{4}-\mathrm{AMoO}_{4}$ $\mathrm{R}_{2}\left(\mathrm{MoO}_{4}\right)_{3}(\mathrm{~A}=\mathrm{Mg}, \mathrm{Mn}, \mathrm{Co}, \mathrm{Ni} ; \mathrm{R}=\mathrm{Cr}, \mathrm{Fe})$," Russian Journal of Applied Chemistry, vol. 76, no. 10, pp. 1572-1576, 2003.

[5] N. M. Kozhevnikova, "Synthesis and study of the variablecomposition phase $\mathrm{Na}_{1-x} \mathrm{Co}_{1-x} \mathrm{Fe}_{1+x}\left(\mathrm{MoO}_{4}\right)_{3}, 0 \leq x \leq 0.4$, with nasicon structure," Russian Journal of Applied Chemistry, vol. 83, no. 3, pp. 384-389, 2010.

[6] V. A. Efremov, V. M. Zhukovskii, and Y. G. Petrosyan, "Phase diagram of the system $\mathrm{Na}_{2} \mathrm{MoO}_{4}-\mathrm{MgMoO}_{4}$," Zhurnal Neorganicheskoi Khimii, vol. 21, p. 209, 1976.

[7] R. F. Klevtsova, V. G. Kim, and P. V. Klevtsov, "An X-ray structural investigation of double molybdates $\mathrm{Na}_{2} \mathrm{R}_{5}\left(\mathrm{MoO}_{4}\right)_{6}$, where $\mathrm{R}=\mathrm{Mg}$, Co, Zn," Crystallography Reports, vol. 25, p. 1148, 1980 (Russian).

[8] G. D. Tsyrenova, S. F. Solodovnikov, E. G. Khaikina et al., "Phase formation in the $\left(\mathrm{Ag}_{2} \mathrm{O}\right)-(\mathrm{MgO})-\left(\mathrm{MoO}_{3}\right)$ system and crystal structure of new $\mathrm{Ag}_{2} \mathrm{Mg}_{2}\left(\mathrm{MoO}_{4}\right)_{3}(\mathrm{M}=\mathrm{Co}, \mathrm{Mn})$," Journal of Solid State Chemistry, vol. 177, no. 6, pp. 2158-2167, 2004.

[9] G. D. Tsyrenova, S. F. Solodovnikov, E. G. Khaikina, and E. T. Khobrakova, "Phase formation in the $\mathrm{Ag}_{2} \mathrm{O}-\mathrm{MgO}-\mathrm{MoO}_{3}$ system and the crystal structure of new double molybdate $\mathrm{Ag}_{2} \mathrm{Mg}_{2}\left(\mathrm{MoO}_{4}\right)_{3}$," Russian Journal of Inorganic Chemistry, vol. 46, no. 12, pp. 1886-1891, 2001.

[10] C. Gicquel-Mayer, M. Mayer, and G. Perez, "Etude Structurale du Molybdate Double d'Argent et de Zinc $\mathrm{Ag}_{2} \mathrm{Zn}_{2} \mathrm{Mo}_{3} \mathrm{O}_{12}$," Acta Crystallographica, vol. 37, pp. 1035-1039, 1981.

[11] C. Gicquel-Mayer and M. Mayer, "Etude Structurale du Molybdate Double $\mathrm{Na}_{0.5} \mathrm{Zn}_{2.75}\left(\mathrm{MoO}_{4}\right)_{3}$," Revue De Chimie Minérale, vol. 19, p. 91, 1982.

[12] A. J. M. Duisenberg, "Indexing in single-crystal diffractometry with an obstinate list of reflections," Journal of Applied Crystallography, vol. 25, no. 2, pp. 92-96, 1992.

[13] A. C. T. North, D. C. Phillips, and F. S. Mathews, "A semiempirical method of absorption correction," Acta Crystallographica, vol. 24, no. 3, pp. 351-359, 1968.

[14] G. M. Sheldrick, "A short history of SHELX," Acta Crystallographica A, vol. 64, no. 1, pp. 112-122, 2007.

[15] G. M. Sheldrick, SHELXS-97-A Program for Crystal Structure Determination, University of Göttingen, Göttingen, Germany, 1997.

[16] K. Brandenburg and M. Berndt, Diamond Version 2.1. Crystal Impact, Bonn, Germany, 2001.

[17] D. Johnson, Zview Version 3.1c, Scribner Associates, 1990-2007.

[18] A. K. Jonscher, "The interpretation of non-ideal dielectric admittance and impedance diagrams," Physica Status Solidi A, vol. 32, no. 2, pp. 665-676, 1975.

[19] L. Sebastian, Y. Piffard, A. K. Shukla, F. Taulelle, and J. Gopalakrishnan, "Synthesis, structure and lithium-ion conductivity of
$\mathrm{Li}_{2-2 x} \mathrm{Mg}_{2+x}\left(\mathrm{MoO}_{4}\right)_{3}$ and $\mathrm{Li}_{3} \mathrm{M}\left(\mathrm{MoO}_{4}\right)_{3}\left(\mathrm{M}^{I I I}=\mathrm{Cr}, \mathrm{Fe}\right)$," Journal of Materials Chemistry, vol. 13, no. 7, pp. 1797-1802, 2003.

[20] N. I. Sorokin, "Ionic conductivity of double sodium-scandium and cesium-zirconium molybdates," Physics of the Solid State, vol. 51, no. 6, pp. 1128-1130, 2009. 

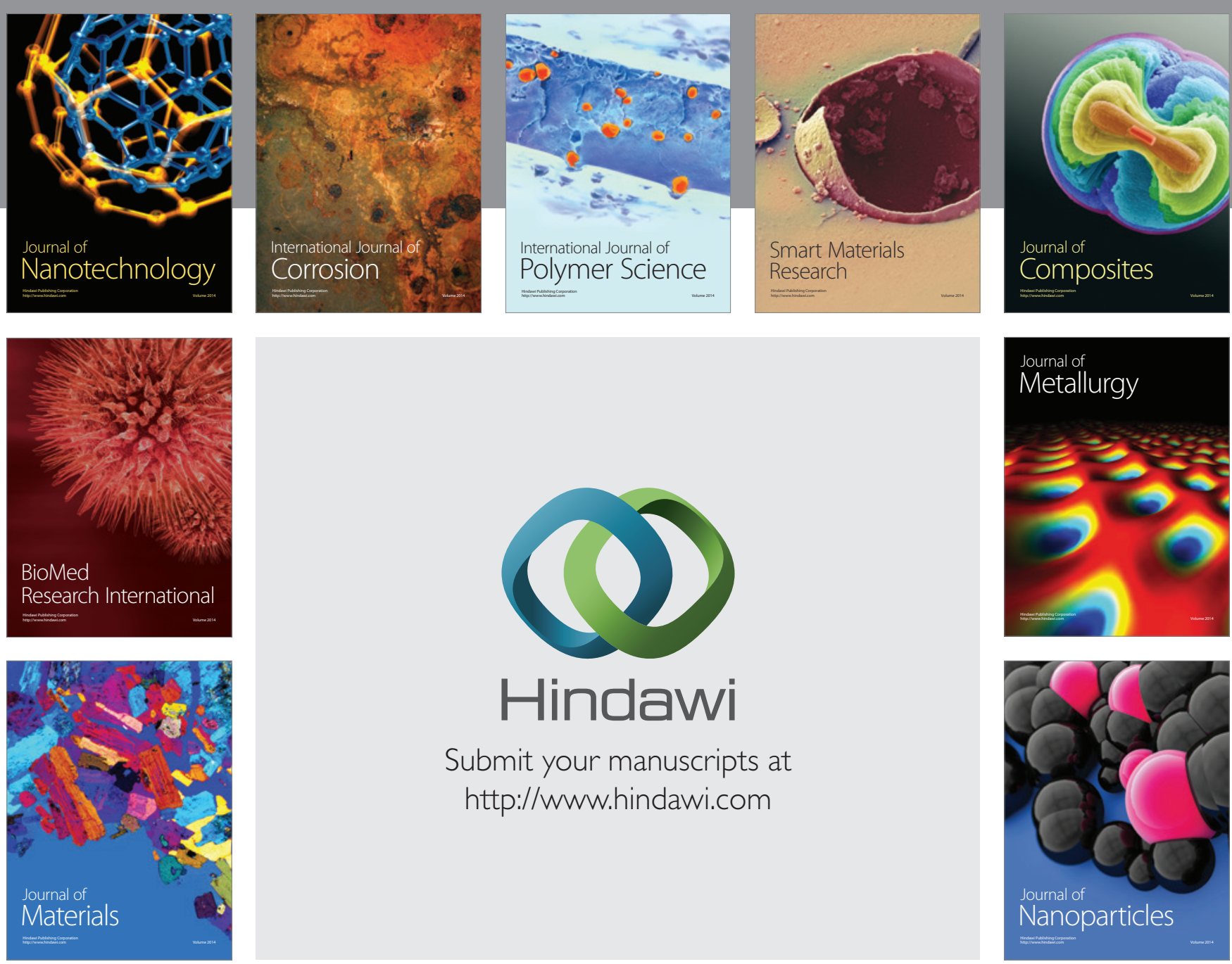

Submit your manuscripts at http://www.hindawi.com
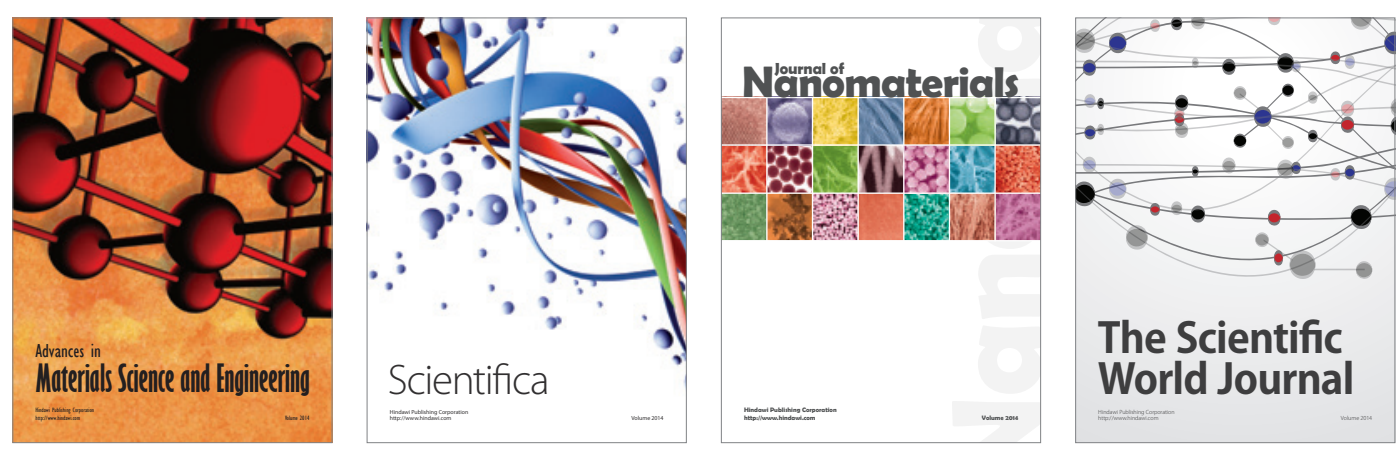

\section{The Scientific World Journal}
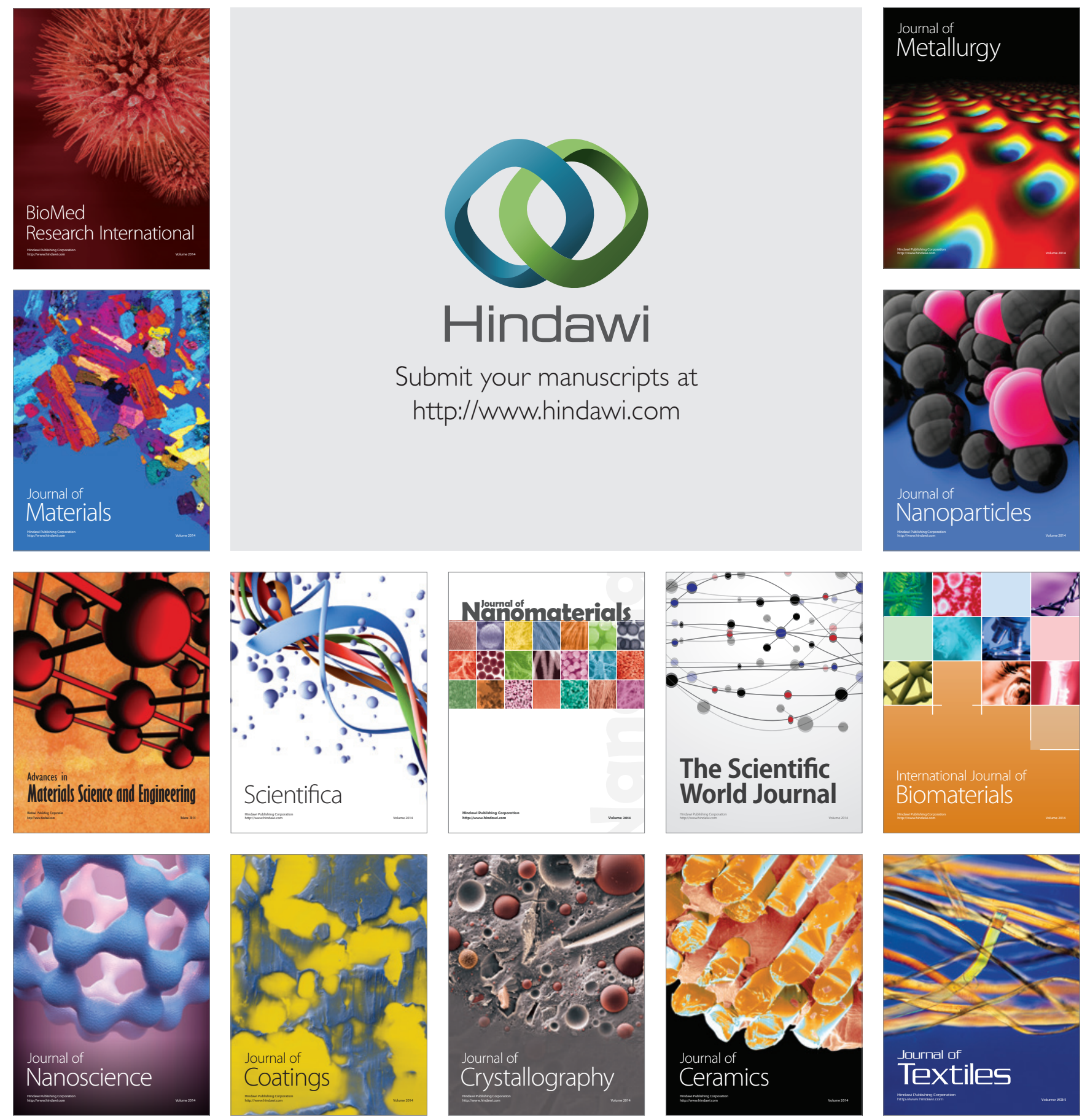